\title{
Endometrial hysteroscopic and histological evaluation in menopausal women in continuous use of raloxifene
}

\author{
Estudo histeroscópico e histológico do endométrio de mulheres menopausadas submetidas à \\ ação continuada do raloxifeno
}

\author{
Vanessa Maria Caetano Soares ${ }^{1}$, Braz Martorelli Filho², Luiz Roberto Araujo Fernandes ${ }^{3}$, Umberto Gazi Lippi ${ }^{4}$
}

\begin{abstract}
Objective: To study the effect of raloxifene on endometrial histopathology of menopausal women. Methods: Thirty-one patients under raloxifene treatment $(60 \mathrm{mg} /$ day $)$ for a six-month period and submitted to diagnostic videohysteroscopy at the Climateric Outpatients Clinic, Department of Gynecology and Obstetrics, Hospital do Servidor Público Estadual Francisco Morato de Oliveira, in the city of São Paulo, and at Hospital Guilherme Álvaro, in the

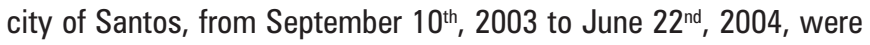
analyzed. Guided endometrial biopsy was performed on all patients on the anterior wall, using a 3-mm or 5-mm biopsy forceps. A 3-mm or 5-mm hysteroscope was used with TV imaging by an endocamera. The results of the hysteroscopic tests were compared before and six months after the use of raloxifene. Results: The comparison between both biopsies was performed by means of the McNemar's test (marginal homogeneity test), and showed a descriptive level of 0.001 that indicates difference between the estrogen effects assessed at different moments. The estrogen effect on the endometrial tissue did not increase in any of the 31 patients analyzed. Twenty-one patients $(68 \%)$ showed smaller estrogen effect in the final evaluation. Conclusions: The study showed no evidence of endometrial stimulation of raloxifene and, in fact, many women presented less estrogen effect after its use.
\end{abstract}

Keywords: Raloxifene; Raloxifene/antagonists \& inhibitors; Raloxifene/ therapeutic use; Endometrium/pathology; Endometrium/drug effects; Estrogen replacement therapy; Postmenopause; Postmenopause/drug effects; Hysteroscopy

\section{RESUMO}

Objetivo: Estudar o efeito do raloxifeno sobre a histopatologia endometrial em mulheres menopausadas. Métodos: Foram estudadas 31 pacientes usuárias de raloxifeno (60 mg/dia) por um período de seis meses e que realizaram vídeo-histeroscopias diagnósticas nos ambulatórios de Climatério do Serviço de Ginecologia e Obstetrícia do Hospital do Servidor Público Estadual "Francisco Morato de Oliveira", São Paulo, e do Hospital Guilherme Álvaro, da cidade de Santos (SP), de 10 de setembro de 2003 a 22 de junho de 2004. Em todas as pacientes foi realizada biópsia endometrial dirigida em parede anterior com pinça de biópsia de 3 ou $5 \mathrm{~mm}$. Os histeroscópios utilizados foram de 3 ou $5 \mathrm{~mm}$ de calibre com visualização da imagem em monitor de televisão por endocâmera. 0s resultados dos exames histeroscópicos foram comparados antes e seis meses após 0 uso do raloxifeno. Resultados: A comparação entre os resultados das duas biópsias, feita por meio do teste de McNemar (teste de homogeneidade marginal), obteve nível descritivo igual a 0,001, 0 que indica diferença entre os efeitos estrogênicos avaliados em diferentes instantes. 0 efeito estrogênico no endométrio não se acentuou em nenhuma das 31 pacientes analisadas. Em 21 pacientes (68\%) foi observado, ao final, menor efeito estrogênico em relação ao exame inicial. Conclusões: 0 estudo não mostrou evidências de que o raloxifeno tenha efeito estimulante sobre 0 endométrio, tendo sido observada inclusive menor ação estrogênica após o uso da droga em um número alto de casos.

Descritores: Raloxifeno; Raloxifeno/antagonistas \& inibidores; Raloxifeno/uso terapêutico; Endométrio/patologia; Endométrio/efeitos de drogas; Terapia de reposição de estrogênios; Pós-menopausa; Pós-menopausa/efeitos de drogas; Histeroscopia

\section{INTRODUCTION}

Raloxifene is a drug of the selective estrogen receptor modulators (SERMs) class, which derives from benzothiophenes. Some researches carried out in the United States and Europe ${ }^{(1)}$ indicate that it raloxifene protects the skeleton against bone loss, inhibiting

\footnotetext{
Study carried out at Hospital do Servidor Público Estadual "Francisco Morato de Oliveira" - HSPE-FMO, São Paulo (SP), Brazil and Hospital Guilherme Álvaro - Santos (SP), Brazil.

'Post-graduate student (Master's degree) at Instituto de Assistência Médica ao Servidor Público Estadual - IAMSPE, São Paulo (SP), Brazil.

${ }^{2}$ PhD, Assistant physician of Department of Gynecology and Obstetrics at Hospital do Servidor Público Estadual "Francisco Morato de Oliveira" - HSPE-FMO, São Paulo (SP), Brazil.

${ }^{3}$ Assistant Professor of Department of Woman at Faculdade de Medicina da Universidade Metropolitana de Santos - UNIMES, Santos (SP), Brazil.

${ }^{4} \mathrm{PhD}$, Full Professor of Obstetrics at Faculdade de Medicina da Universidade Metropolitana de Santos - UNIMES, Santos (SP), Brazil.

Corresponding author: Vanessa Maria Caetano Soares - Avenida Ana Costa, 222 conj. 55 - Vila Mathias - CEP 11060-001 - Santos (SP), Brazil - Tel.: (13) 3222-6342 - E-mail: vanessa@allnetwork.com.br

Received on: Feb 19, 2009 - Accepted on: Dec 17, 2009
} 
resorption and significantly increasing bone mineral density. There is also evidence of favorable effects on many risk factors for cardiovascular diseases, such as: drop in LDL-cholesterol, increase in HDL-cholesterol, reduction in fibrinogen and lipoprotein $(\mathrm{a})^{(2-3)}$. It also seems to be a valid alternative to reduce the higher risk of coronary disease in postmenopausal women. It is certainly necessary to wait for the results of future clinical trials to definitely establish the benefits in this clinical context. SERMs may be an ideal option for postmenopausal women at risk of osteoporosis, with family history or risk factors for cardiovascular disease, family history/fear of breast cancer, resistant or unable to receive hormone replacement therapy ${ }^{(1)}$. It was also demonstrated $^{(4-5)}$ that raloxifene, like other SERMs, exerts antagonist effect on breast tissue, inhibiting estrogen-dependent proliferation of human breast cancer cells in vitro and the development of breast tumors induced in rats in vivo.

Raloxifene does not seem to have any stimulating effect on the endometrium ${ }^{(4,6)}$. Data collected from three studies $^{(7)}$ comparing $60 \mathrm{mg} /$ day raloxifene to placebo, estrogen therapy (ET) and combined estrogen and progesterone therapy (EPT) demonstrated that the incidence of metrorrhagia in women receiving raloxifene was similar to that found among those who were taking placebo, and the incidence of metrorrhagia was higher in the group treated with estrogen, as well as in the estrogen-progesterone group. It was also observed ${ }^{(6,8)}$ that, since metrorrhagia is not expected among women receiving raloxifene, the patients should undergo a previous assessment of endometrial thickness to rule out pre-existing endometrial problems.

\section{OBJECTIVES}

The objective of the present study was to assess the action of the drug on the endometrium of a group of women, whose characteristics are described below, using hysteroscopy and biopsy, followed by histopathology.

\section{METHODS}

Thirty-one menopausal women from the Climateric Outpatients Clinics at Hospital Guilherme Álvaro, Centro Universitário Lusíada, in the city of Santos, and at Hospital Servidor Público Estadual "Francisco Morato de Oliveira", in the city of São Paulo, were studied between September 10 2 th 2003 , and June 22 ${ }^{\text {nd }}, 2004$. The inclusion criteria were: age over 40 years, be menopausal, no endometrial disease detected by clinical history, gynecologic examination or transvaginal pelvic ultrasound (endometrial thickness at ultrasound equal to or lower than $4 \mathrm{~mm}$ ) and indication for use of raloxifene.
The exclusion criteria comprised use of sexual steroids in the six-month period before the present study, use of intrauterine device (IUD) or hormonal intrauterine contraceptives in the last six months, contraindicated use of the drug (past or present history of venous thromboembolic events or important vasomotor symptoms).

The indications for using the substance in the series herein presented were family history of osteoporosis in 10 cases $(32.3 \%)$ and sedentary lifestyle in 21 (67.7\%).

The mean age was 60.9 years and the standard deviation was 6.6. The majority of participants were Caucasians (29, $93.5 \%)$. Two $(6.5 \%)$ were of black origin.

The dose of raloxifene utilized was $60 \mathrm{mg} /$ day in the morning for six months. The endometrium was assessed by means of hysteroscopy and pathology in the beginning of treatment and at the end of the six-month period.

All endoscopies were performed after obtaining a signed informed consent at the outpatients clinic, and $3(9.6 \%)$ patients needed local anesthesia. Two types of hysteroscopes were used: a 3-mm, $25^{\circ}$, Wolff, and a $5-\mathrm{mm}, 30^{\circ}$, Storz. The uterine distension was performed using carbon dioxide and controlled electronically by means of a Storz hysteroflator. A videocamera system was used to record several exams in colored videoprinter images.

The samples for pathology were obtained through endometrial biopsies: one before using the drug (baseline), and another six months later. The biopsies were guided using a 3- or 5-mm biopsy forceps, and the specimen was removed from the anterior uterine wall. The histopathology was carried out at the Pathology Departments of the Hospitals, as follows.

The specimens collected were placed in containers with a $10 \%$ formaldehyde solution to be processed in the laboratories. They were examined with regard to color, texture, consistency and volume before being imbedded in paraffin block for histology. Hematoxylineosin staining was used and a Zeiss microscope with a 400x lens. Hystometric eyepiece was also used.

Eventual endometrial histological and hysteroscopic changes after raloxifene were studied. The biopsies were assessed through estrogen score according to Boss et al. and based on basal criteria of proliferative estrogenic induction when compared to the typical endometrium of menopausal women ${ }^{(3,9)}$.

Table 1 depicts the individual score of biopsies according to morphologic changes.

Table 2 shows the estrogenic score: score of endometrial morphologic changes and grade of estrogenic effects.

McNemar's test (marginal homogeneity test) was employed to compare the results of both evaluations. 
Table 1. Score of endometrial biopsies per morphological changes, according to Boss et al. ${ }^{(9)}$

\begin{tabular}{|c|c|c|c|}
\hline Morphological changes & None $*(0)$ & Limited (1) & Plenty (2) \\
\hline \multicolumn{4}{|l|}{ Glandular effects } \\
\hline Shape & Small, tubular, straight & Straight & Cystic or open, tortuous \\
\hline Nucleus/cytoplasm ratio & Very high (> 75\%) & Moderate $(50-75 \%)$ & Low $(50 \%)$ \\
\hline Pseudostratification & None & Limited & Diffuse \\
\hline Mitoses & None & Rare & Many \\
\hline \multicolumn{4}{|l|}{ Estromal effects } \\
\hline \multicolumn{4}{|l|}{ Other effects } \\
\hline Metaplasias & None & Rare & Some \\
\hline Tissue volume & Rupture or weakly intact & Moderate - Practically intact & Abundant - intact \\
\hline
\end{tabular}

*Score between brackets

Table 2. Estrogen score of morphological changes and estrogen effect grade, according to Boss et al. ${ }^{(9)}$

\begin{tabular}{lcc}
\hline Score & $\begin{array}{c}\text { Estrogen effect } \\
\text { grade }\end{array}$ & Description \\
\hline $0-3$ & 0 & $\begin{array}{c}\text { Typical postmenopausal endometrium with } \\
\text { little or no estrogen effect } \\
\text { Estrogen effect present, but limited }\end{array}$ \\
$4-6$ & 1 & Significant estrogen effect \\
$7-10$ & 2 & Marked estrogen effect \\
$>10$ & 3 &
\end{tabular}

\section{RESULTS}

Table 3 depicts the sample distribution concerning the initial assessment, before using the drug, with regard to the estrogenic effect over the endometrium and the distribution of this sample after six months of treatment.

Table 3. Pre and post-treatment estrogen effect

\begin{tabular}{|c|c|c|c|c|}
\hline \multirow{2}{*}{ Estrogen effect } & \multicolumn{2}{|c|}{ Pre-treatment } & \multicolumn{2}{|c|}{ Post-treatment } \\
\hline & $\mathbf{n}$ & FR\% & $n$ & FR\% \\
\hline Little or no estrogen effect (Score 0) & 8 & 25.8 & 29 & 93.5 \\
\hline Limited estrogen effect (Score 1) & 23 & 74.2 & 2 & 6.5 \\
\hline Total & 31 & 100 & 31 & 100 \\
\hline
\end{tabular}

FR\%: percentage relative frequency

It is important to point out that greater endometrial activity was not detected. Out of the 31 patients studied, $21(68 \%)$ had alterations in the initial state, migrating from score 1 to score 0 , which means less endometrial activity.

After comparing the results of both evaluations by means of McNemar's test, the value of $p=0.001$ was obtained, which indicates a significant difference between the estrogenic effects assessed at different periods of time.

\section{DISCUSSION}

The SERMs have been studied with regard to their potential agonist and antagonist effects in comparison to sexual steroids in different tissues. Such selective activity is due to their interaction with the intranuclear estrogen receptor, leading to conformational changes in the receptor, which may inhibit the effect of estrogen or induce gene transcription. Nevertheless, there are some hindrances in the administration of SERMs ${ }^{(10,11)}$. The vasomotor symptoms common in the postmenopausal period may not respond to those agents as they do to hormone replacement therapy. Other authors ${ }^{(7)}$ observed that most heat waves occur in the first six months of treatment and are rarely seen after that. Besides, most are mild to moderate. Only a small percentage of women have severe symptoms. There was no difference between raloxifene and placebo concerning other symptoms, such as sleep disorders. On examining the frequency of cramps in the lower limbs of the same population, it was noticed that the incidence increases with age, and this undesired effect it significantly more frequent with raloxifene as compared to placebo. In the present study, none of the 31 studied patients had to discontinue treatment due to vasomotor symptoms.

Raloxifene plays a relevant role in the treatment of osteoporosis after menopause in a large population of women subjected to considerable increase in frequency of vertebral fractures ${ }^{(7,10)}$.

Researches in rats demonstrated that the treatment with this drug reduces the weight of the uterus ${ }^{(1,12)}$.

Another study, carried out in rats after oophorectomy ${ }^{(13)}$ which received either raloxifene or estrogen during one year, demonstrated different effects in histological characteristics of the endometrium. A marked proliferation of gland cells and increased endometrial thickness were initially found in the endometrium of the rodents receiving the hormone. After use of raloxifene, the histological aspect was similar to that of oophorectomized rats, with no thickening and little proliferation of gland cells.

The current study corroborates theses results about endometrial histological effects, since the estrogenic 
effect in group II (six months after use of raloxifene) showed that $68 \%$ of the 31 studied women had less estrogenic activity from the endometrial standpoint (reduced endometrial thickness and scarce proliferation of gland cells). Such results must be considered due to the interface of use of raloxifene with the menopausal state of the patients concerned; that is, there may be two concurrent factors leading to decreased estrogen activity in the endometrium.

Different clinical studies involving raloxifene ${ }^{(14,15)}$ aimed to assess the endometrial effects of the drug in large populations. For instance, the endometrial thickness and the size of the uterus were evaluated by transvaginal ultrasound and, in a subgroup of patients, the histological pattern was assessed by endometrial biopsy. Thickening of this tissue, increased uterine size and histological signs of endometrial alteration due to the estrogenic effect in women on raloxifene were not observed.

Some placebo-controlled studies $^{(1)}$ with roughly 3,000 women receiving raloxifene during at least six months demonstrated an incidence of metrorrhagia of $2.9 \%$ among the patients under treatment with the drug, and of $3.9 \%$ in those receiving the placebo. In the present study, there were no cases of metrorrhagia.

In two multicenter placebo-controlled studies conducted in about 2,200 patients in Europe and the United States, the effect of raloxifene on endometrial thickness was assessed by ultrasound. After two years of treatment, it was not possible to detect differences in endometrial thickness between the two groups. It suggests that the use of the drug is safe with regard to the effects on increased endometrial thickness, which is associated to hyperplasia and endometrial cancer ${ }^{(11)}$.

It is also under investigation whether there are differences in the uterine effect in women submitted to hormone therapy with estrogen associated with medroxyprogesterone and to raloxifene. After one year of treatment, the size of the uterus did not change in women treated with raloxifene, and there was a significant increase amongst those who received hormone replacement therapy. As to endometrial thickness, at the end of the first year of treatment, a significantly higher increase was observed amongst women receiving hormone replacement therapy when compared to those who received raloxifene. Miometrial biopsy was performed in 43 patients of the raloxifene group who, at the beginning of the treatment, presented inactive atrophic endometrium. During the whole period, all patients sustained the same histological characteristics. On the other hand, among the 37 patients of the hormone replacement therapy group with basal endometrial atrophy, 12 presented proliferative alterations and uterine polyps. The partial results of these studies indicated that the use of raloxifene is extremely safe in terms of estrogen effects on the endometrium $^{(1,16)}$. Such results are in accordance to the findings of the present study.

A large multicenter study conducted in Canada, United States, Belgium and Denmark assessed the use of raloxifene in postmenopausal women during five years and demonstrated preservation of bone mineral density, significant reduction of progression of osteoporosis, antiproliferative effects in breasts and no association with increased rates of vaginal bleeding, endometrial hyperplasia or endometrial cancer when compared to placebo $^{(6,17)}$.

\section{CONCLUSIONS}

In the present study there was no histopathological evidence of endometrial stimulus in menopausal women using raloxifene; indeed, in $68 \%$ of the patients a smaller estrogen effect on the endometrium was observed.

\section{REFERENCES}

1. Agnusdei D, Cannalis E, Johnston C, Wenger NK, Uribe AM. SERMS Una nueva alternative para la salud de la mujer en la posmenopausia. Cancun: Acindes; 1997.

2. Balfour JA, Goa KL. Raloxifene. Drugs Aging. 1998;12(4):335-41.

3. Delmas PD, Bjarnason NH, Mitlak BH. Effects of raloxifene on bone mineral density, serum cholesterol concentrations and uterine endometrium in postmenopausal women. New Engl J Med. 1997;337(23): $1641-7$.

4. Abdullah KN, Raoof A, Raoof M. Effectiveness and safety of raloxifene in postmenopausal females. J Coll Physicians Surg Pak. 2005;15(5):266-9.

5. Jordan VC. Chemoprevention of breast cancer with selective oestrogenreceptor modulators. Nat Rev Cancer. 2007;7(1):46-53.

6. Christodoulakos GE, Botsis DS, Lambrinoudaki IV, Papagianni VD, Panoulis CP, Creatsa MG, et al. A 5-year study on the effect of hormone therapy, tibolone and raloxifene on vaginal bleeding and endometrial thickness. Maturitas. 2006;53(4):413-23.

7. Cauley J, Forbes J, Mautalen C. Diminuição do risco de câncer de mama na América Latina: dados atuais e métodos futuros. Buenos Aires: Acindes; 2004.

8. Botsis D, Christodoulakos G, Papagianni V, Lambrinoudaki I, Aravantinos L, Makrakis $E$, et al. The effect of raloxifene and tibolone on the uterine blood flow and endometrial thickness: a transvaginal Doppler study. Maturitas. 2006;53(3):362-8

9. Boss SM, Huster WJ, Neild JA, Glant MD, Eisenhut CC, Draper MW. Effects of raloxifene hydrochloride on the endometrium of postmenopausal women. Am J Obstet Gynecol. 1997;177(6):1458-64.

10. Tremollieres F, Ribot C. Raloxifene in postmenopausal women. Gynecol Obstet Fertil. 2006;34(2):147-53.

11. Neven P, Quail D, Marin F, Creatsas G, Depypere $H$, Rechberger $T$, et al. Comparing raloxifene with continuous combined estrogen-progestin therapy in postmenopausal women: Review of Euralox 1. Maturitas. 2005;52(2):87101.

12. Moraes AVS, Simões RS, Fonzar LF, Simões MJ, Soares Junior JM, Haidar $M A$, et al. Efeitos da terapia estro-raloxifeno sobre o endométrio de ratas. Rev Bras Ginecol. 2006;28(2):101-6. 
13. Cicinelli E, Pinto V, Tinelli R, Saliani N, De Leo V, Cianci A. Rapid endometrial preparation for hysteroscopic surgery with oral desogestrel plus vaginal raloxifene: a prospective, randomized pilot study. Fertil Steril. 2007;88(3): 698-701.

14. Azevedo GD, Prado MF, Ferriani RA, Reis RM, Berezowski AT, Ribeiro TF, et al. Raloxifene therapy does not affect uterine blood flow in postmenopausal women: a transvaginal Doppler study. Maturitas. 2004;47(3):195-200.
15. Tsalikis T, Zepiridis L, Zafrakas M, Dinas K, Bontis J. Endometrial lesions causing uterine bleeding in postmenopausal women receiving raloxifene. Maturitas. 2005;51(2):215-8.

16. Nozaki M. Effects of raloxifene on the other organs without bone: uterus. Clin Calcium. 2004;14(10):55-60.

17. Jolly EE, Bjarnason NH, Neven P, Plouffe L Jr, Johnston CC Jr, Watts SD, et al. Prevention of osteoporosis and uterine effects in postmenopausal women taking raloxifene for 5 years. Menopause. 2003;10(4):337-44. 